\title{
Patients with suspected myocardial infarction: their test request patterns for clinical biochemistry in a British and a Canadian cardiac care unit
}

\author{
AR HENDERSON,* MARY D GARDNER $\dagger$ \\ From the *Department of Clinical Biochemistry, University Hospital, University of Western Ontario, Ontario, \\ Canada, and the $\dagger$ Department of Biochemistry, Royal Infirmary, Glasgow, Scotland
}

SUMMARY The total number of routine clinical biochemistry tests requested for patients admitted to a coronary care unit with a diagnosis of "query myocardial infarction" were recorded over four to eight months. There were 156 sequential admissions in a British teaching hospital and 163 in a Canadian counterpart; the incidence of confirmed myocardial infarction was $53 \%$ and $50 \%$, respectively. The pattern of tests ordered was substantially similar in each unit, unlike the rate of testing. For example, total creatine kinase was requested five times less often per patient in the British hospital than in the Canadian unit in cases of confirmed myocardial infarction $(2 \cdot 17$ and $10 \cdot 17$, respectively; $p<0.0001$ ): the difference was much less, but still significant, when there was no infarction $(2.01$ and $3.55 ; \mathrm{p}<0.0001)$. This study suggests a significant international difference in the use of clinical biochemistry services between coronary care units. Physicians (clinical and laboratory) need to be more critical of their use of protocols, which may prove wasteful of limited health care resources.

A move from a British to a Canadian teaching hospital showed that there seemed to be more clinical biochemistry testing performed per hospital bed in the Canadian hospital than in the British equivalent. This impression was subsequently confirmed by a survey (circa 1977) of one year's workload in three British and three Canadian tertiary care teaching hospitals (Table 1). ${ }^{1}$

The British and Canadian test numbers form two distinct populations (with the exception of magnesium requests), with Glasgow Royal Infirmary and University Hospital, Canada, being fairly representative of each national grouping.

In general, we found that Canadian clinicians request up to eight times as many tests/inpatient as their British counterparts. This finding was confirmed by a detailed survey of our two hospitals. ${ }^{2}$ It could, of course, be argued that these differences were due to differing case mix groupings in each country. A subsequent study, ${ }^{3}$ however, showed that even in a well defined case grouping (regular haemodialysis for end stage renal failure) there was more than a four fold difference in test request patterns between countries, although policies regarding admissions to haemo-

Accepted for publication 11 February 1986 dialysis units do differ between countries. ${ }^{4}$

We examined the extent of clinical chemistry testing in an even more circumscribed group-those with acute myocardial infarction. We accept that the optimum rate of sampling for serum enzyme activity determinations in a patient with suspected myocardial infarction remains controversial and that there may be wide variations in interhospital use; indeed, serum enzyme determinations may not be necessary at all for most such cases. On the basis of a careful and thoughtful study, Werner et al proposed that the assay of two serum enzyme activities (creatine kinase (EC 2.7.3.2; CK) isoenzyme 2 and lactate dehydrogenase (EC 1.1.1.27; LD), or $\alpha$-hydroxybutyrate dehydrogenase (no EC number; $\alpha$ HBD)) on two consecutive days was adequate. ${ }^{5}$ Speicher and Smith $^{6}$ reviewed the many alternative sampling routines (all based on creatine kinase and lactate dehydrogenase and their isoenzymes) that have been suggested for confirming (or excluding) the diagnosis of myocardial infarction. These routines include: sampling at time of admission and thereafter at 12 hourly intervals for the first 48 hours; three samples on admission, at six to 13 hours, and at 24 to 37 hours after admission; sampling at six to eight hourly intervals; and sampling at eight hourly intervals for the first $\mathbf{4 8}$ hours. 
Table 1 Selected test numbers for three Canadian and three British teaching hospitals (Data are expressed as tests per 1000 inpatient days)

\begin{tabular}{|c|c|c|c|c|c|c|}
\hline & \multicolumn{3}{|l|}{ Britain } & \multicolumn{3}{|l|}{ Canada } \\
\hline & St George's* group & $G R I \dagger$ & Tayside group $\ddagger$ & $U H \S$ & $T G H^{* *}$ & $M G H \eta$ \\
\hline $\begin{array}{l}\text { Total No of acute care beds } \\
\text { Total No of acute inpatient days } \\
\text { Average acute care stay (days) } \\
\text { Potassium } \\
\text { Magnesium } \\
\text { Glucose } \\
\text { Cholesterol } \\
\text { Creatine kinase } \\
\text { Digoxin }\end{array}$ & $\begin{array}{l}820 \\
238455 \\
10 \cdot 2 \\
164^{\mathrm{a}} \\
6 \\
75 \\
8 \\
1 \\
4\end{array}$ & $\begin{array}{l}1557 \\
504468 \\
7 \cdot 5 \\
161^{b} \\
10 \\
42 \\
12 \\
20 \\
4\end{array}$ & $\begin{array}{l}1400 \\
453600 \\
10 \cdot 3 \\
126^{c} \\
3 \\
53 \\
19 \\
2 \\
2\end{array}$ & $\begin{array}{l}390 \\
119662 \\
11.9 \\
512^{d} \\
5 \\
606^{d} \\
60 \\
48 \\
9\end{array}$ & $\begin{array}{l}1090 \\
329792 \\
10 \cdot 4 \\
338^{\mathrm{e}} \\
15 \\
491^{\mathrm{f}} \\
24 \\
28 \\
27\end{array}$ & $\begin{array}{l}900 \\
21568 \\
11.9 \\
295^{\mathrm{a}} \\
3 \\
453^{\circ} \\
273^{9} \\
39 \\
10\end{array}$ \\
\hline
\end{tabular}

a channel analyser; ${ }^{b}=7$ channel analyser; ${ }^{c}=11$ channel analyser; ${ }^{d}=13$ channel analyser; ${ }^{c}=6$ and 4 channel analyser;

$f=6$ channel analyser; ${ }^{\circ}=12$ channel analyser; ${ }^{*}$ The hospitals associated with St George's Hospital, London, England; tGlasgow Royad Infirmary, Scotland; the hospitals associated with Ninewells Hospital, Dundee, Scotland; §University Hospital, London, Ontario, Canadạ ***Toronto General Hospital, Toronto, Ontario; \Montreal General Hospital, Montreal, Quebec.

All these routines derive from laboratories in American hospitals. A standard Brtish text ${ }^{7}$ suggests that if a single sample is to be taken after myocardial infarction it should coincide with peak serum enzyme activity. Otherwise, the text suggests, three samples (like those described above) would adequately confirm (or exclude) the provisional diagnosis of myocardial infarction.

We therefore decided to determine whether the difference in patterns of the use of clinical biochemistry in cardiac (coronary) care units in our two representative hospitals was similar to the patterns described previously. ${ }^{1-3}$

\section{Material and methods}

\section{PATIENT POPUlATIONS AND ClASSIFICATION}

Three hundred and nineteen patients with a tentative diagnosis of "query myocardial infarction" admitted ${ }_{\mathrm{c}}^{\infty}$ to the cardiac care units of either Glasgow Royalo Infirmary (GRI) or University Hospital (UH) were included in this study. At GRI 156 sequential admis-c sions from July 1984 to October 1984 were recorded; at UH the study group consisted of 163 sequential $\vec{c}$ admissions from October 1984 to May 1985. Diagno-o sis was based on standard criteria ${ }^{8}$ of clinical history, electrocardiographic findings, and serial enzymeo changes.

Table 2 lists the tests for which both units sento "routine bloods" to the laboratory, according to a setoำ protocol established by the physicians in each unit. In $\mathbb{Q}$ addition to the routine unit protocol, there is, of course, a need to request discretionary tests (such as 3 blood gases, drug assays, and so on). During our survey these tests comprised less than $1 \%$ of those of? the routine protocols. The methods in use in each

Table 2 Test request patterns in cardiac care units

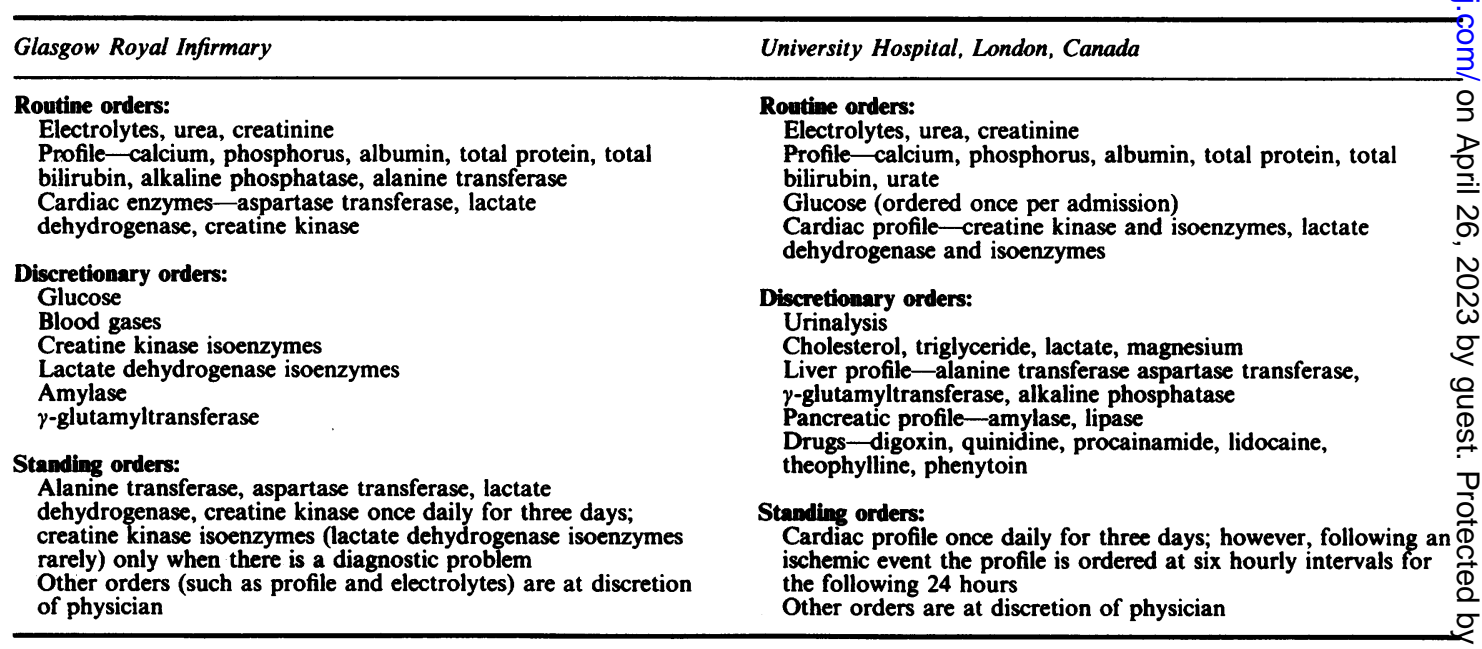


Table 3 Test requests for patients in the cardiac care unit of Glasgow Royal Infirmary (values are mean (SD)) $\dagger$

\begin{tabular}{|c|c|c|c|c|c|c|}
\hline Days spent in cardiac care unit & $\begin{array}{l}\text { Electrolytes, urea, } \\
\text { and creatine }\end{array}$ & Profile* & $\begin{array}{l}\text { Aspartase } \\
\text { transferase }\end{array}$ & $\begin{array}{l}\text { Alanine } \\
\text { transferase }\end{array}$ & $\begin{array}{l}\text { Creatine } \\
\text { kinase }\end{array}$ & $\begin{array}{l}\text { Lactate } \\
\text { dehydrogenase }\end{array}$ \\
\hline \multicolumn{7}{|c|}{$\begin{array}{l}\text { Patients without myocardial infarction }(n=72) \\
2.43(1.4)\end{array}$} \\
\hline $\begin{array}{l}\text { Tests per patient per day } \\
\text { Tests per patient }\end{array}$ & $\begin{array}{l}1 \cdot 0-0(0) \dagger \\
4 \cdot 0-0(0) \dagger\end{array}$ & $\begin{array}{l}0.38(0.33) \\
0.76(0.59)\end{array}$ & $\begin{array}{l}0.89(0.25) \\
2.03(1.05)\end{array}$ & $\begin{array}{l}0.90(0.24) \\
2.04(1.05)\end{array}$ & $\begin{array}{l}0.89(0.25) \\
2.01(1.05)\end{array}$ & $\begin{array}{l}0.89(0.25) \\
2.01(1.05)\end{array}$ \\
\hline \multicolumn{7}{|c|}{$\begin{array}{l}\text { Patients with myocardial infarction }(n=82) \\
3.00(1.35)\end{array}$} \\
\hline $\begin{array}{l}\text { Tests per patient per day } \\
\text { Tests per patient }\end{array}$ & $\begin{array}{l}2 \cdot 0-0(0) \dagger \\
6 \cdot 0-0(0) \dagger\end{array}$ & $\begin{array}{l}0.35(0.28) \\
0.85(0.58)\end{array}$ & $\begin{array}{l}0.77(0.29) \\
2 \cdot 17(1.05)\end{array}$ & $\begin{array}{l}0.77(0.29) \\
2.17(1.05)\end{array}$ & $\begin{array}{l}0.77(0.29) \\
2.17(1.03)\end{array}$ & $\begin{array}{l}0.77(0.29) \\
2.17(1.03)\end{array}$ \\
\hline
\end{tabular}

*as defined in Table 2; tmany patients had no tests performed in these categories and ranges (median values) have been inserted instead.

hospital have already been described. ${ }^{29}$

We used the $F$ test to compare sample variances and Student's $t$ test to compare the interhospital data. ${ }^{10} \mathrm{~F}$ and $t$ values were calculated using the Epic Statistics Package (Epic Systems Corporation, Madison, Wisconsin, United States of American).

\section{Results}

The pattern of tests carried out on coronary care unit patients differed between the hospitals (Table 2); clearly, a more extensive spectrum of enzyme testing was carried out at UH than at GRI. For example, the isoenzymes of creatine kinase and lactate dehydrogenase were routinely assayed on all patients in the coronary care unit at $\mathrm{UH}$, whereas only one creatine kinase isoenzyme assay (and no lactate dehydrogenase isoenzyme assays) were carried out on the group of 154 patients during the entire study period at GRI, because these assays were not deemed to be necessary on clinical grounds.

Tables 3 and 4 list the average number of days spent in the coronary care unit and the principal tests requested. Although there was no interhospital difference for the average length of stay in the coronary care unit for patients without myocardial infarction, there was a highly significant difference $(p$ $<0.0001)$ between hospitals for requests of total cre- atine kinase and lactate dehydrogenase. For patients with confirmed myocardial infarction the average interhospital length of stay in the coronary care unit was significantly different $(p<0.0001)$, as were the number of enzyme assays per patient per day ( $p<$ 0.0001 ). The mean number of enzyme assays (expressed as per patient per day) was less in the GRI group with confirmed myocardial infarction than in the group without myocardial infarction. If the data are expressed as assays/patient then the longer the length of stay of patients with a myocardial infarction, the more assays are requested.

The data-for example, the number of total creatine kinase assays listed in Tables 3 and $4-$ must be converted to average numbers of assays per patient to appreciate the difference in the rate of testing between hospitals; the average number of requests for creatine kinase assays on patients who did not have myocardial infarction becomes 2.01 (GRI) and 3.55 (UH), and the number of requests on patients with myocardial infarction becomes $2 \cdot 17$ (GRI) and 10.17 (UH). Thus there is a five fold interhospital difference in the number of creatine kinase assays per patient requested on patients with myocardial infarction while they occupy a bed in the coronary care unit. At UH lactate dehydrogenase and lactate dehydrogenase isoenzymes are done together; creatine kinase isoenzymes will only be performed if the total creatine

Table 4 Test requests for patients in the cardiac care unit of University Hospital, London, Canada (values are mean $(S D))+$

\begin{tabular}{|c|c|c|c|c|c|c|c|}
\hline $\begin{array}{l}\text { Days spent in cardiac care } \\
\text { unit }\end{array}$ & $\begin{array}{l}\text { Electrolytes, urea, } \\
\text { and creatine }\end{array}$ & Profile* & Urinalysis & $\begin{array}{l}\text { Creatine } \\
\text { kinase }\end{array}$ & $\begin{array}{l}\text { Creatine } \\
\text { kinase } \\
\text { isoenzymes }\end{array}$ & $\begin{array}{l}\text { Lactate } \\
\text { dehydrogenase }\end{array}$ & $\begin{array}{l}\text { Lactate } \\
\text { dehydrogenase } \\
\text { isoenzymes }\end{array}$ \\
\hline \multicolumn{8}{|c|}{$\begin{array}{l}\text { Patients without myocardial infarction }(n=84) \\
2.57(1.14)\end{array}$} \\
\hline $\begin{array}{l}\text { Tests per patient per day } \\
\text { Tests per patient } \\
\text { Patients with myocardial inf } \\
4.74(2.09)\end{array}$ & $\begin{array}{l}2-0(0) \dagger \\
5 \cdot 0(0) \dagger \\
\text { retion }(n=81)\end{array}$ & $\begin{array}{l}0.42(0.37) \\
0.99(0.81)\end{array}$ & $\begin{array}{l}1-0(0) \\
2-0(0)+\end{array}$ & $\begin{array}{l}1.46(0.92) \\
3.55(2.45)\end{array}$ & $\begin{array}{l}0.62(0.81) \\
1.64(2 \cdot 32)\end{array}$ & $\begin{array}{l}1.43(0.9) \\
3.48(2.41)\end{array}$ & $\begin{array}{l}1.43(0.9) \\
3.48(2 \cdot 41)\end{array}$ \\
\hline $\begin{array}{l}\text { Tests per patient per day } \\
\text { Tests per patient }\end{array}$ & $\begin{array}{l}1.67-0(0) \dagger \\
13-0(0) \dagger\end{array}$ & $\begin{array}{l}0.29(0.27) \\
1.16(0.92)\end{array}$ & $\begin{array}{l}1-0(0) \\
3-0(0) \dagger\end{array}$ & $\begin{array}{l}2 \cdot 22(0 \cdot 94) \\
10 \cdot 17(5 \cdot 11)\end{array}$ & $\begin{array}{l}1.94(0.98) \\
8.98(5.06)\end{array}$ & $\begin{array}{l}2.15(0.93) \\
9.89(5.04)\end{array}$ & $\begin{array}{l}2.15(0.94) \\
9.86(5.06)\end{array}$ \\
\hline
\end{tabular}

*as defined in Table 2; †many patients had no tests performed in these categories and ranges (median values) have been inserted instead. 
kinase is above a certain activity; thus $46 \%$ of patients without myocardial infarction and $88 \%$ of those with myocardial infarction had creatine kinase isoenzymes assayed.

\section{Discussion}

We previously documented the increased use of clinical biochemistry services by Canadian physicians compared with that of their British counterparts. ${ }^{1-3}$ We speculated that the numbers of clinical biochemists employed in a clinical biochemistry laboratory (who could perform a "gatekeeper" function) probably had some effect on ordered test patterns. The effectiveness of this function has been shown in three separate studies. ${ }^{11-13}$ The exposure of medical students and physicians in training to instruction on appropriate testing strategies might also have been a factor in reducing laboratory use. ${ }^{14} 15$

Before discussing the implications of our findings it is appropriate to compare our data with those of Griner $^{15}$ for the internal medicine service of the Strong Memorial Hospital (a teaching hospital in the University of Rochester (New York Medical School). He showed (circa 1977) that there were $85 \cdot 2$ creatine kinase requests per 1000 inpatient days; these compare with the range (expressed in similar units) of 1 to 48 (Table 1) for all inpatients in the six hospitals that we studied. Griner's other data are also comparable with those obtained from our Canadian survey of three hospitals. The data provided by Martin et al ${ }^{16}$ for the medical service of the Brigham and Women's Hospital in Boston (Massachusetts) circa 1977 were also very similar to our Canadian data. Would these data be valid now for use in our comparisons? We think so, and Showstack et $a l^{17}$ have shown that laboratory costs (in 1982 dollars) remained constant at the University of California, San Francisco, for patients with myocardial infarctions over the three years, 1972, 1977, and 1982. This finding means that test numbers remained constant, whereas in the same years imaging costs for these patients increased five fold: Canadian and American test ordering practices do seem to be very similar.

Klein ${ }^{18}$ has suggested that differences in medical cultures are probably as important as differences in the availability of resources (although we must emphasise that GRI is better equipped for clinical biochemistry services than UH). Klein makes the important suggestion that Britain is an "original sin society in which illness and debility are seen as part of the natural order," leading to a "humane, clinical conservationism," whereas America (and, we believe, Canada) is a "perfectability of man society in which illness and debility are seen as challenges to action" leading to an "heroic aggressive style of medicine" and, we believe, a concomitant heavy use of the labo- $\frac{0}{\vec{\sigma}}$ ratory. Certainly the examples we have given of the investigational protocols tend to confirm this suggestion, as do the differences documented in Tables 1 今 and 3 , and 4 . Is the laboratory being overused? Eisen- 0 berg et $^{1} \mathrm{l}^{19}$ found a $50 \%$ overuse of lactate dehy- 음 drogenase requests using the technique of retro- $\frac{\bar{s}}{7}$ spective chart audit; Martin et al $^{16}$ in a much quoted $\stackrel{\otimes}{\Omega}$ study, showed that modifying the test ordering behav-

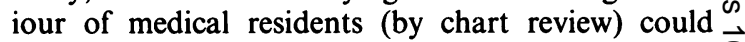
reduce the number of laboratory requests by $50 \%$. Surprisingly, in such studies in Britain reductions in $\vec{\omega}$ test numbers have also been claimed, or obtained, $\stackrel{\circ}{\circ}$ although these reductions are proportionately less용 because use is initially much less. ${ }^{2021}$

Rudolph Klein suggested that there was an international (medico) cultural difference. ${ }^{18}$ If we examine $o$ the pattern of requests in relation to the respective $\underset{\mathcal{O}}{\mathcal{O}}$ published normative advice for each country, ${ }^{67}$ bear- $\mathrm{O}$ ing in mind that the first $\mathbf{4 8}$ hours of a hospital stay is the standard window for testing, then GRI probably has a more appropriate pattern of testing than UH₹ (Table 3). This is most evident when these data are $\vec{\bullet}$ converted to tests per patient-for example, the aver- $\stackrel{\infty}{\circ}$ age number of creatine kinase requests per patient for a patient with myocardial infarction in GRI is $2 \cdot 17$; it is $10 \cdot 17$ at $\mathrm{UH}$.

The data presented here suggest to us, particularly in the north American context, that the style of labo- $\frac{\varnothing}{\Phi}$ ratory management of patients in coronary care units $\varrho$ should be changed. Instead of using an ordering pro- $\overrightarrow{\overrightarrow{0}}$ tocol, a more useful mechanism might be an ordering 3 algorithm that would explicitly incorporate already available test results. For example, would a physician necessarily require creatine kinase isoenzymes if the creatine kinase activity had peaked? Would further:lactate dehydrogenase isoenzymes be necessary if the 3 . LD-1 or LD-1:LD-2 ratios had progressed from normal to abnormal? This concept of feedback is implicit in the process of medical diagnosis; it is nullified in our $\mathrm{O}$ view by the existence of test protocols. These protocols do not usually incorporate modifications for cur- $\frac{D}{0}$ rent test results as this would negate their primary purpose. Support for our view comes from a recent $\sigma$ symposium on cost containment in cardiology. As $N$ routine orders increase unnecessarily the cost of N admissions to coronary care units it was recommen- $\sigma$ ded that these orders could be modified to minimise the cost of inpatient treatment. ${ }^{22}$ This group of experienced cardiologists went so far as to describe the concept of routine orders as "a fallacy."

We believe that is is now time for physicians to $\frac{0}{0}$ justify-in clinical and economic terms - the volume, $\mathbb{\mathbb { D }}$ spectrum, and style of testing that they use in coro- $\frac{\sim}{\mathbb{D}}$ nary care units. The mechanisms for such assessments $\frac{}{\square}$ are available. ${ }^{23-25}$ 
We are grateful for the cooperation of the staff of the coronary care units in both hospitals. This study was supported by a grant (AN 047) from the Ontario Heart and Stroke Foundation.

\section{References}

${ }^{1}$ Henderson AR, Gardner MD, Griffiths PD, et al. Clinical chemistry usage in Britain and Canada. $N$ Engl J Med 1980;303:113-4.

${ }^{2}$ Henderson AR, Gardner MD. Clinical chemistry laboratory productivity; a comparison between a Canadian and a British teaching hospital. J Clin Pathol 1981;34:44-8.

${ }^{3}$ Gardner MD, Henderson AR. Test-request patterns for clinical chemistry in a British and a Canadian renal dialysis unit. Clin Chem 1983;29:1546-8.

${ }^{4}$ Aaron HJ, Schwartz WB. Matters of life and death. In: The painful prescription: rationing hospital care. Washington DC: Brookings Institution, 1984:29-56.

${ }^{5}$ Werner M, Brooks SH, Mohrbacher RJ, Wasserman AG. Diagnostic performance of enzymes in the discrimination of myocardial infarction. Clin Chem 1982;28:1297-302.

${ }^{6}$ Speicher CE, Smith JW. Cardiovascular subproblems. Choosing effective laboratory tests. Philadelphia: WB Saunders, 1983: 155-82.

${ }^{7}$ Whitby LG, Percy-Robb IW, Smith AF. Enzyme tests in diagnosis. Lecture notes on clinical chemistry. 3rd ed. Oxford: Blackwell Scientific Publications, 1982:138-68.

${ }^{8}$ Report of the Joint International Society and Federation of Cardiology/World Health Organization Task Force on Standardization of Clinical Nomenclature. Nomenclature and criteria for diagnosis of ischemic heart disease. Circulation 1979; 59:607-9.

${ }^{9}$ Henderson AR. The test request form: a neglected route for communication between the physician and the clinical chemist? $J$ Clin Pathol 1982;35:986-98.

${ }^{10}$ Sokal RR, Rohlf FJ. Biometry: the principles and practice of statistics in biological research. 2nd ed. San Francisco: WH Freeman, 1981:128-207.

${ }^{11}$ Smith ADS, Shenkin A, Dryburgh FJ, Morgan HG. Emergency biochemistry services-are they abused? Ann Clin Biochem
1982;19:325-8.

12 Young RM, Payne RB. Effectiveness of out-of-hours biochemistry investigations. $\mathrm{Br}$ Med J 1981;283:289-91.

${ }^{13}$ Morgan DB, Gunn IR, Faye S, Clegg G, Grant AM. A comparison of alternate arrangements for an out-of-hours chemical pathology service. Lancet 1985;i:859-61.

${ }^{14}$ Grivell AR, Forgie JH, Fraser CG, Berry MN. Effect of feedback to clinical staff of information on clinical biochemistry requesting patterns. Clin Chem 1984;27:1717-20.

${ }^{15}$ Griner PF, medical house staff. Use of laboratory tests in a teaching hospital: long term trends. Ann Intern Med 1979;90:243-8.

${ }^{16}$ Martin AR, Wolf MA, Thibodeau LA, Dzau V, Braunwald E. A trial of two strategies to modify the test-ordering behaviour of medical residents. $N$ Engl J Med 1980;303:1330-6.

${ }^{17}$ Showstack JA, Stone MH, Schroeder SA. The role of changing clinical practices in the rising costs of hospital care. $N$ Engl J Med 1985;313:1201-7.

${ }^{18}$ Klein R. Rationing health care. Br Med J 1984;289:143-4.

${ }^{19}$ Eisenberg JM, Williams SV, Garner L, Viale R, Smits H. Computer-based audit to detect and correct overutilization of laboratory tests. Med Care 1977;15:915-21.

${ }^{20}$ Sandler G. Costs of unncessary tests. Br Med J 1979;ii:21-4.

${ }^{21}$ Young DW. An aid to reducing unnecessary investigations. $\mathrm{Br}$ Med J 1980;281:1610-1.

${ }^{22}$ Harrison DC, Rapaport E, Thibault GE. Workshop II: cost control issues in acute myocardial infarction and coronary care management-points of view. Am J Cardiol 1985;56:65C-9C.

${ }^{23}$ Drummond MF. Principles of economic appraisal in health care. Oxford: Oxford University Press, 1980.

${ }^{24}$ Drummond MF. Studies in economic appraisal in health care. Oxford: Oxford University press, 1981.

${ }^{25}$ Department of clinical epidemiology and biostatistics, McMaster University Health Sciences Centre. How to read clinical journals. VII. To understand an economic evaluation. Can Med Assoc J 1984;130:1428-74, 1542-9.

Requests for reprints to: Dr AR Henderson, Department of Clinical Biochemistry, University Hospital, PO Box 5339, Postal Station A, London, Ontario, Canada N6A 5A5. 